\title{
BARNAMEZŐS TERÜLETEK REHABILITÁCIÓJA BUDAPESTEN
}

\author{
(Rehabilitation of Brownfields in Budapest)
}

\section{KUKELY GYÖRGY - BARTA GYÖRGYI - BELUSZKY PÁL - GYÖRI RÓBERT}

Kulcsszavak:

barnamezö városrehabilitáció városfejlesztés funkcióváltás

Az elnúlt tizenöt évben az ipari funkciójú területek városon belüli elhelyezkedése alapvetöen megváltozott Magyarországon. A közel száz éves iparfejlödés során kialakult ipari telephelyeket egyre inkább körbenötte a város, amely több problemát is felvetett. Ugyanakkor felerösödöt a dezindusztrializáció, az. ipari terïletek egy részére már nem volt szükség a termeléshez. Az ingatlanpiac is megélénkült, s felgyorsult e terilletek funkcióváltása. Az ún. barnamezös területek a városfejlesztés központi kérdésévé váltak, hatékony újrahasznosításuk érdekében beavatkozásra van szilkség.

A barnamező (brownfield) fogalma az amerikai szakirodalomban a korai 1980-as években bukkant fel elöször, s egyszerüen az elhagyott ipari területeket jelentette akkoriban. Ahogy egyre több fejlett országban terjedtek a dezindusztrializációs folyamatok, e fogalom is gazdagodott, és eltérỏ tartalmakat kapott (Alker-JoyRoberts-Smith 2000; Jackson-Garb 2002). Az Európai Unióban a CLARINET (Contaminated Land Rehabilitation Network Technologies) munkacsoport megfogalmazása szerint a brownfield az a hely, amelyet elözöleg használtak már, jelenleg elhagyott, vagy kevésbé hasznosított; feltárt vagy feltételezett szennyezettségi problémákkal küszködik; föként a városi térségben található; a hatékony újrahasznosítása érdekében beavatkozásra van szükség (Ferber-Grimski 2002,9).

Kutatásunkban a következő barnaövezeti meghatározást alkalmaztuk: A barnamezös területek kisebb hatékonysággal hasznositott (alulhasznositott), esetenként kiürült, volt iparterületek. De ide soroljuk a rosszul hasznositott, vagy elhagyott vasúti, és a már kiürült katonai területeket is (Barta 2002). A kömyezeti szennyezettség általános - de még többnyire feltáratlan - problémájához hasonlítható gondot jelent a tulajdonviszonyok rendezetlensége, valamint a felmerülő problémák átfogó jogi szabályozatlansága. A barnamezös területek rendkívül nagy aránya - a nyugati országokhoz hasonlítva - minöségi különbséget jelent a problémák kezelésében.

A barnaövezeti lehatárolás kapcsán definiálnunk kell a következỏ alapfogalmakat:

- átmeneti terület: a belváros és a kertváros között elhelyezkedö térség, amely tartalmazza a barnamezőt és a hozzákapcsolódó, nagy kiterjedésủ mezőgazdasági területeket, zöldterületeket (temetỏk, parkok, sportpályák stb.), valamint a közlekedés-szállítás térségeit.

- barnamezös térség, barna zóna: ez a tradicionális (volt) ipari terület, kỏzlekedési, lakótelepi zárványokkal. Gyakorlatilag kutatásaink szükebb vizsgálati 
Kukely György - Barta Györgyi - Beluszky Pál - Győri Róbert: Barnamezős területek rehabilitációja Budapesten. - Tér és Társadalom, 20. 2006. 1. 57-71. p.

területe. (Budapest területének 13\%-a, kb. $68 \mathrm{~km}^{2}$ ). Egy része már megújult, vagy most van ebben a fázisban.

- rozsdaövezet: a barnamezös térség még meg nem újult területe, azok a térségek, amelyeket korábban intenzíven hasznosítottak - ipari, közlekedési, raktározási területek, laktanyák, esetleg lakóterületek stb. -, ám hasznosításukkal felhagytak, vagy annak intenzitása erösen visszaesett (s amely területeken rendszerint a felhagyott tevékenység feleslegessé vált, leromlott infrastruktúrája - elhagyott üzemépületek, raktárak, iparvágányok stb. - is megtalálhatók).

\section{Barnamezös kutatások az MTA RKK-ban}

Az MTA Regionális Kutatások Központja Budapesti Osztálya évek óta foglalkozik a budapesti barnaövezet problémáival. Első vizsgálatunk célja Budapest barnaövezetének lehatárolása és a jelenlegi területhasználat feltárása volt (Barta 2002). Ez a vizsgálat lehetőséget nyújtott az egységes fogalomrendszer kidolgozásához, valamint a területi lehatárolás módszertanának kifejlesztéséhez. A kutatás során kérdöíves felmérést végeztünk a lehatárolt térségben az ezredfordulón is müködö, mintegy 2000 vállalatban. A kutatás számos - addig nem ismert - összefüggésre hívta fel a figyelmet, például, a vállalati telekgazdálkodás, telek-tulajdonviszonyok szempontjaira, amelyek mindenféle térségi megújítás kulcskérdését jelentik. A kutatás lezárásakor megállapítható volt, hogy szükségessé válik a barna zóna gazdaságának, vállalatai történetének feltárása, a vasúti és a honvédségi területek vizsgálata, a környezet állapotának feltérképezése, az átalakuló-megszúnő vállalatok tulajdonviszonyainak, a bérleti rendszereknek részletesebb elemzése, a barnaövezet ingatlanpiaci pozícióinak, folyamatainak vizsgálata, az önkormányzatok - fővárosi és kerületi - szerepének tisztázása.

Ezt követte az európai nagyvárosok barnaövezeteiben alkalmazott rehabilitációs megoldásokat bemutató kutatás (Barta 2004a). A nyugat-európai városi esettanulmányok hasznos tapasztalatokkal szolgáltak néhány kérdésben: hogyan kezelik a környezeti kármentesítés kérdéseit, milyen akadályokat jelentenek a barnaövezeti megújulásban a közigazgatási és terủetfejlesztési rendszer ellentmondásai, milyen szerepet töltenek be a városi önkormányzatok a rehabilitáció menedzselésében, hogyan vonhatók be a város gazdasági és közösségi szereplői a tervezésbe és a tervek végrehajtásába.

Ezt követỏen széleskörü kutatási együttmúködéssel (építész, várostervezö, ingatlanszakértö, történész, geográfus, közgazdász és szociológus szakértők bevonásával) végeztük el a budapesti barnaövezet átfogó vizsgálatát (Barta 2004b). Bemutattuk a budapesti ipar kialakulását, fénykorát és visszahúzódását; a kialakult barnaövezet kiterjedését, határait és hasznosítását; a környezeti szennyezettséget, a kiürült, romos, de sokszor értékes épületeket, a bezárt gyárak közé szorult, általában nyomorúságos lakótelepek nehéz örökségét, a megújulás spontán jeleit, s a területrendezés és városfejlesztés elképzeléseit e térséggel kapcsolatban. 
Kukely György - Barta Györgyi - Beluszky Pál - Győri Róbert: Barnamezős területek rehabilitációja Budapesten. - Tér és Társadalom, 20. 2006. 1. 57-71. p.

TÉT XX. évf. 2006 - 1

Barnamezös területek ...

\section{Az ipari térszerkezet átalakulása Budapesten}

Budapesten már a 19. század közepén körvonalazódtak azok az iparnegyedek, melyek egészen 1990-ig - összezsugorodva napjainkig - befogadták az ipartelepek zömét. Az iparnegyedek a város mai közigazgatási területének mintegy 15-16\%-át tették ki. Az elmúlt évtizedekben sem a gazdaságpolitika, sem a városfejlesztőrendező politika nem tudta érdemlegesen befolyásolni az ipar területi elhelyezkedését a fövárosban.

A rendszerváltás után a piacgazdasági viszonyok közepette a ráfizetéses, korábban az állam által mesterségesen életben tartott vállalatokat felszámolták, a KGST megszünése számos vállalat számára nagyarányú piacvesztéssel járt. Erőteljes dezindusztrializáció indult el Budapesten: a gazdasági struktúrában az ipar részaránya csökkent, és egyre inkább átadja helyét a szolgáltató ágazatnak. Számos ipartelepen megszűnt a termelés, a meglévő ipari épületek más funkciót (raktározási, kereskedelmi, irodaházi stb.) kaptak vagy magukra hagyottan pusztultak. Nagykiterjedésü, az ipar által elhagyott területek alakultak ki Budapesten.

A tulajdonviszonyok, a gazdasági struktúra átalakulása, valamint az ingatlanpiac egyre jobban érzékelhető hatása révén gyökeresen megváltozott az ipar térbeli elhelyezkedése a fövárosban (Kiss 1999; Barta 2004b). A tulajdonosi rendszer megváltozása - főleg a privatizáció révén - a telkek és ingatlanok térbeli szétaprózódásához vezetett. Az ipari tevékenység visszaszorulásával zsugorodni kezdtek a müködỏ iparterületek. A kedvezö városszerkezeti pozíciójú térségekben, főleg Budapest északi részén (elöször a Váci út mentén, ill. a lágymányosi térségben), ahol az ingatlanpiaci árak relatíve magasabbak voltak, azonnal megindult a gazdasági szerkezetváltás, az ipar helyét a szolgáltatások, illetve a lakófunkciók foglalták el. A város déli, délkeleti felében inkább a leépülés, a lassú átstrukturálódás, az ipar részleges továbbélése volt jellemzö. Nagyméretü ingatlanok ürültek ki, kiterjedt térségek váltak átmenetileg hasznosítottá. E romló pozíciójú térségekben az ingatlanhasznosítást megnehezítik a rendezetlen tulajdonviszonyok, a környezetszennyezettség, valamint a kiürült iparterületek közé szorult, rossz állapotú lakótelepek problémái. A privatizáció során felbukkant a spekulációs tőke is. Megindult a korábban összefüggő iparterületek mozaikos felaprózódása (tulajdonosi, gazdaságszerkezeti, területi szempontból egyaránt).

Az új gazdaság helyfoglalásával, a gazdasági szereplők megsokszorozódásával, a vállalkozások agglomerálódásával, hálózatosodásával, valamint a szállítás és közlekedés iránti megnövekedett igényekkel a területigény is extrém módon növekszik. Ezzel függ össze a másik jelentős térbeli változás, a gazdasági szuburbanizálódás. $\mathrm{Az}$ ingatlanpiaci hatások következtében a barnamezős rehabilitációval szemben a zöldmezös beruházás vált előnyössé, gazdaságossá a városszéli és városkörnyéki területeken. A budapesti agglomeráció szerkezetformáló folyamatairól elmondható, hogy jobbára területfejlesztési koordináció nélkül zajlanak (elegendỏ az agglomerációs települések ingatlanpolitikájára, vagy a közlekedésfejlesztés vég nélküli vitáira gondolnunk), részleteikben bizonytalan jövöbeli következményekkel. A Budapest környéki zöldmezős gazdasági területek széttagolt, strukturálatlan kínálatának fel- 
Kukely György - Barta Györgyi - Beluszky Pál - Győri Róbert: Barnamezős területek rehabilitációja Budapesten. - Tér és Társadalom, 20. 2006. 1. 57-71. p.

60 Kukely Gy.-Barta Gy.-Beluszky P.-Györi R.

TÉT XX. évf. 2006

pörgése mutatja a nagyvárosi térségben kibontakozó - a globalizációhoz is köthető - léptékváltást, a régiós méretü, egyelöre eléggé szervezetlen folyamatokat.

Mindemellett, a budapesti ipari koncentráció - a maga 115 ezer munkahelyével ma is a legnagyobb az országban. A budapesti ipar 1994 után újra növekedési pályára került. Az ipari fejlödés főként a kủlföldi beruházások kezdetben domináló, de jelenleg is magas (bár kétségtelenül csökkenő) arányának köszönhető. A budapesti barnaövezet továbbra is a fóvárosi gazdaság kitüntetett fontosságú tere, s kiterjedt gazdaságnak, sok, kisebb-nagyobb vállalatnak ad helyet. A barnaövezet részaránya a budapesti gazdaságban a következő adatokkal jellemezhető: területaránya 13\%-os, a ma múködő vállalatok 5\%-a található itt, s a foglalkoztatottak 24\%-a dolgozik e térségben. A vállalatok erỏs fluktuációja, a gazdasági struktúraváltozás jellege, az épületek külsö állapota arra enged következtetni, hogy a barnaövezet mai gazdasága, vállalatai még átmeneti helyzetben vannak.

\section{Budapest barnaövezetei}

Budapest összefüggő ipari térségei markáns övezetet alkotnak. Ez az (egykori) ipari övezet része annak a köztes, átmeneti zónának, amely a nagyvárosokban sủrün beépített belvárosi lakóövezet és az (alapvetően) kertvárosias beépítésű elővárosok/külvárosok között alakul ki. Az átmeneti övezetben található ipari-közlekedési hasznosítású (barnaövezeti) térségeken belül jelöltük ki a rozsdaövezeteket. Körülhatárolhatóak a rozsdaövezetekkel együtt kezelhető, extenzíven hasznosított területek is, melyek egy esetleges városfejlesztési, -rendezési akció során bevonhatók az akcióterületbe. A következö terület-típusokat alakítottuk ki (1. ábra).

1) Eredetileg (1990 táján), nagyobb - legalább háztömbnyi - területre kiterjedő ipari, közlekedési, raktározási funkciójú, ill. speciális hasznosítású (pl. szemétlerakó, külszíni bányaterület stb.) területek, függetlenül pillanatnyi állapotuktól. Az így körülhatárolt területeknek csak egy része sorolható a szủkebb értelemben vett barnaövezethez. E területegységeken belül, a mai állapotuk alapján - a megújulást és a lepusztulást figyelembe véve - többféle altípust lehet elkülöníteni: befejezett funkcióváltáson átesett, rendezödött helyzetü területek; az eredeti tevékenységet folytató, stabil funkciójú területek; az eredeti tevékenységgel felhagyott, ideiglenes hasznosítású területek; a korábbi hasznosítás intenzitásának csökkenése miatt ,alulhasznosított” ipari, közlekedési stb. területek; elhagyott ipari, raktározási stb. területek. Ezen altípusok közül a szúkebb értelemben vett rozsdaterületek közé az ideiglenes hasznosítású, az elhagyott és a csökkent intenzitású tevékenységet folytató ipari-közlekedési stb. területek sorolhatók.

2) A barnaterületekkel együtt kezelendó területek sorába került néhány alacsony laksürủségü, leromlott állagú lakóterület. 
Kukely György - Barta Györgyi - Beluszky Pál - Győri Róbert: Barnamezős területek rehabilitációja Budapesten. - Tér és Társadalom, 20. 2006. 1. 57-71. p.

\section{1. ÁBRA}

A budapesti barnaövezet és egyéb extenziven használt területek

(The Brownfield and Other Extensively Utilized Areas in Budapest)

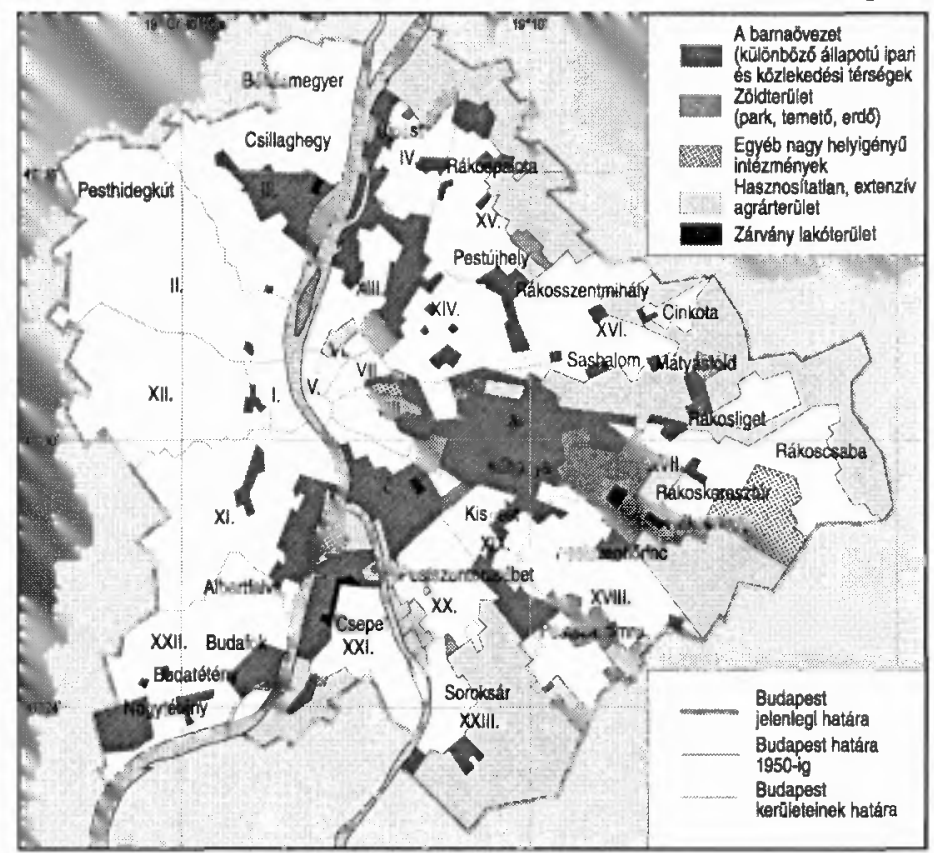

Forrás: Beluszky-Gyóri 2004.

3) Hasznosítatlan vagy igen extenzíven hasznosított területek, ill. mezögazdasági müvelés alatt álló területek kiterjedése nagy a föváros közigazgatási határán belül. A velük való ,gazdálkodás” sok szempontból megoldatlan (pl. a tulajdonviszonyok, a belterületbe való vétel körüli problémák, természetvédelmi kérdések, a mezőgazdasági területek védelmének speciális kérdései stb.).

4) Az ipari-közlekedési terekhez kapcsolódó nagyobb kiterjedésú zöldterületek helyzete-sorsa többnyire független a barnaövezetet érintő kérdésektöl, néhány esetben viszont összefügghet vele ( $\mathrm{pl}$. a Hajógyári-sziget részben zöldterület, részben a volt hajógyár ideiglenes jelleggel hasznosított területe). Hasonló a helyzete néhány nagy helyigényủ intézménynek (pl. a Ferihegyi repülőtér).

\section{Mindezek alapján megállapítható:}

- Budapest - eredeti funkcióját tekintve - ipari-közlekedési területeinek kiterjedése tekintélyes, kb. $68 \mathrm{~km}^{2}$, a föváros közigazgatási területének 13\%-a. $\mathrm{Ha}$ azonban a föváros közigazgatási területéhez tartozó mezögazdasági és zöldterületektöl eltekintünk - a Budai-hegység erdöterületei! -, az ipari-közlekedési térségek aránya a beépített terület közel 30\%-ára növekszik.

- A barnamezős térség határozott övezeti rendet mutat, ezen belül területének zöme nagy, összefüggő területi egységeket alkot. Az ipari-közlekedési zóna a 19. század végére kialakult zárt, intenzív pesti lakóövezet határa, az ún. Város- 
Kukely György - Barta Györgyi - Beluszky Pál - Győri Róbert: Barnamezős területek rehabilitációja Budapesten. - Tér és Társadalom, 20. 2006. 1. 57-71. p.

62 Kukely Gy.-Barta Gy.-Beluszky P.-Györi R.

TÉT XX. évf. 2006 a 1

árok vonala (Haller utca - Orczy út - Fiumei út - Thököly út - Dózsa György út - Dráva utca) és Kis-Budapest közigazgatási határa között formálódott ki. E „kiflinek” csak két csúcsa nyúlik át a budai oldalra, a Hajógyári-sziget és Külsö-Óbuda területére, ill. délen Kelenföld Duna-parti városrészére. Ezen övezettől befelé a vasútvonalak mentén nyomul előre az ipari-közlekedési terület, kifelé pedig néhány, eredetileg Kis-Budapest közigazgatási határán kívül fekvő ipari elöváros területén (Budafok, Csepel, Újpest). Az övezet területébe nagy helyigényủ - nem ipari-forgalmi - intézmények ékelődnek (zöldterületek, sportpályák stb.).

- A barna-övezet hangsúlyos városszerkezeti elem. Egyértelmủen elkülöníti egymástól a belső lakóövezetet és a peremkerületek jobbára extenzívebben hasznosított lakóterületeit. A barna-övezet s a nagy helyigényü intézmények Kerepesi temető, Népliget, Városliget, a pályaudvarok stb. - masszív ,akadály-zónát" képeznek a belső és a külső kerületek között, több helyütt csak szúk korridorok biztosítanak összeköttetést a két makroszerkezeti egység között. A külső kerủletek felzárkóztatása megköveteli az ,,akadálymentesítést”, a barna-zóna átjárhatóságának biztosítását.

- A belső lakóövezet, a barna-zóna, illetve a nagy helyigényủ intézmények zónája és a külsô területek lakóövezeteinek gyürüs rendszere csak a pesti oldalon alakult ki egyértelmủen, Budán - részben a domborzati viszonyok következtében - csupán néhány területfolton jelentkezik a barna-zóna.

A budapesti barnaövezet - elsősorban topográfiai elhelyezkedése alapján - három nagy szektorra különül el:

Az északi szektor a III., IV., XIII., XV., XVI. kerület barnamezős területeit, a föváros egyik legkorábbi ipari városrészét öleli fel. A fóvárosból kivezető közlekedési tengelyekre (Váci út, Szentendrei út) felfüzve hosszan nyúlnak el az ipari területek a mai közigazgatási határok felé. Forgalmi helyzete jó, ez megindította a terület modernizálódását, funkció-váltását. Ezt elsősorban az ipari szektor csekély, illetve a kereskedelmi-szolgáltató tevékenység magasabb részaránya igazolja. Különösen a belső városrészekhez közel - hasonló ,belvárosias" funkciókra tettek szert, elsősorban lakossági szolgáltatásokat végeznek. Mindemellett, ezek a tengelyek a főváros kỏzigazgatási határain túl nem folytatódnak ,városkapu” jellegủ területekben.

A keleti szektor magjai a Köbányát közrefogó vasúti fővonalak mentén alakultak ki, s a X., XVI. és a XVIII. kerületek barna zónáit foglalja magában. Ipari - szállítási - raktározási terület. Befelé is elörenyomulnak az ipari területek egészen a zárt beépítésủ lakóövezetig - a Ganz VIII. kerületi üzeme -; másutt viszont a nagy helyigényủ intézmények vannak a belső lakóterületek és az ipari negyedek között (Kerepesi temető, Népliget, pályaudvarok). A barnaövezetbe lakótömbök ékelödnek, gyakorta az egyes telektömbök is vegyes hasznosításúak. Az átalakulás itt lassabban megy végbe: az 1989 elött alakult vállalatok kezében van a vállalati telkek döntő többsége (gyógyszergyárak, nyomdák, sörgyárak stb.). A lassabb funkcióváltás föleg a kedvezőtlenebb közlekedési és városszerkezeti helyzettel függ össze (így 
Kukely György - Barta Györgyi - Beluszky Pál - Győri Róbert: Barnamezős területek rehabilitációja Budapesten. - Tér és Társadalom, 20. 2006. 1. 57-71. p.

TÉT XX. évf. 2006 - 1

Barnamezös területek ...

a kiskereskedelem és egyéb lakossági szolgáltatások térhódítása is korlátozottabb). De megjelentek már az új, vagy megújult forgalmi központok, gócok is (pl. az M2 metróvégállomás környékén). A keleti szektorban kimondottan sürgető feladat az alig vagy rosszul hasznosított vasúti területek rendezése.

A déli szektor a IX., XVIII., XX., XXI., a budai oldalon pedig a XI. és XXII. kerület ipari-közlekedési övezeteit foglalja magában. Csepelen, a szigetcsúcson nagykiterjedésủ mezőgazdasági, ill. hasznosítatlan területek kapcsolódnak az ipari zónákhoz. A Duna és a ráckevei Duna-ág egyértelmủen elkülöníti a szektor három fő egységét (Külső-Ferencváros, Csepel, ill. Kelenföld). Együttes „,kezelésüket” egy új Duna-híd felépülése tenné lehetövé. Az átalakulás ebben a szektorban a leglassabb: még jelenleg is az ipari tevékenység dominál (a vállalati telkek közel felén ipari tevékenység folyik), de szintén jelentős a szállítási - raktározási profillal rendelkezö vállalatok részaránya. Közlekedési helyzete kedvezőbb, mint a keleti szektoré, az újonnan kiépített vagy felértékelödött útvonalak mentén, környékén gyorsabb a gazdasági átalakulás. Ám az ipari negyedeken belüli közlekedést (pl. Csepelen) megnehezíti a volt ,nagyvállalati birodalmakat” átszelő utak, utcák hiánya. A déli szektorban kiterjedtebb az átmeneti területhasznosítás. Nagy gondja ennek a térségnek a környezeti kármentesítés. Így e szektor megújulása elképzelhetetlen néhány nagy-volumenü kormányzati-önkormányzati akció nélkül (pl. új Duna-híd, gerincutak kiépítése, a környezetszennyezés megszüntetése, a vasúti területek hatékonyabb használata).

\section{Funkcióváltás a barnaövezetben}

A nagyvárosok barnaövezeteiben jelentös spontán funkcióváltás megy végbe. A korábbi ipari üzemek, laktanyák telephelyein és a vasúti területeken új tevékenységek jelennek meg. A barnaövezetek rehabilitációja elsősorban az ipari tevékenységek megszünését követő tulajdonosi szerkezet átalakulásával, és az ingatlanpiac igényeinek átrendezödésével vált hangsúlyossá 1990 után. A barnamezök városi pozíciója is sok esetben megváltozott. A belvároshoz közelebb lévő és esetleg más szempontból is kedvezỏ adottságú ipari területeken funkcióváltás ment végbe. Az egyre zsúfoltabbá váló belváros terjeszkedésével a korábbi ipari területeken a magasabb hozzåadott-értéket termelö funkciók nyernek teret (pénzügyi szolgáltatás, üzleti tanácsadás, informatika, kereskedelem, adminisztratív munkahelyek), illetve megjelenhetnek a szabadidős, kulturális funkciók, de akár lakófunkció kialakításăra is lehetöség adódik (pl, az ún. loft-lakások megjelenése).

A privatizáció során sok terület hasznosítása során megjelent a spekuláció, az új tulajdonosok átmeneti használatot követően az ingatlan továbbadásában voltak érdekeltek. Minél nagyobb tőkeerejü társaság lett a végsỏ hasznosító, annál jobban érvényesült a bontás, átalakítás és új építés, s annál kevésbé volt szempont a telephely eredeti arculatát meghatározó építészeti emlékek megörzése. A kedvező helyzetü ipari területeken az épületek átalakítása, szanálása könnyebben és olcsóbban megoldható volt, mint a belvárosi üzleti negyedben. A metró- és villamos-vonalak közelében, nagy átmenö forgalommal rendelkezö csomópontokon a korábbi tevékenység jelentősen 
Kukely György - Barta Györgyi - Beluszky Pál - Győri Róbert: Barnamezős területek rehabilitációja Budapesten. - Tér és Társadalom, 20. 2006. 1. 57-71. p.

visszaszorult, s új funkciók jelentek meg. Az eredeti épületek legtöbbjét itt lebontották, és új irodaházat, bevásárlóközpontot (Duna Plaza, WestEnd City Center, MOM Park stb.), tudományos és technológiai parkot (Infopark, Graphisoft Park) létesítettek a telken. Ezek jellemzöen kedvező hatással voltak az ingatlanárak alakulására is, hiszen jelentős kisugárzást gyakoroltak a környékük presztízsének növekedésében, s így pozitív hatással voltak a térség fejlődésére is.

A kedvezőtlenebb fekvésü barnamezőkön is lejátszódott funkcióváltás, de itt elsősorban a korábbi épületek hasznosítására került sor, $\mathrm{s}$ az addigi termelö tevékenységet egyszerúen felváltotta a kereskedelmi, raktározási, logisztikai funkció.

Fontos kérdéssé vált az ipari emlékek megörzése és hasznosítása, egyre jelentösebb a korábbi ipari épületek kulturális célú használata is (pl. a Trafó, a MEO, a Fonó, a budai Ganz Villamossági Mủvek helyén felépített Millenáris Park, de az Óbudai Gázgyár és a Közraktárak hasznositására is hasonló tervek vannak).

\section{A barnaövezeti rehabilitáció kulcskérdése: a környezet állapota}

Az ipari termelés hanyatlásával a barnaövezet területén egykor mủködö üzemek környezetszennyezése megszünt, vagy jelentös mértékben csökkent. Környezeti problémaként nem is elsősorban a területen megjelenő új tevékenységek, funkciók okozta terhelések jelentkeznek. Sokkal súlyosabb gondot jelentenek az örökölt környezeti károk, ezen belül is a legnagyobb problémát környezetvédelmi, s egyben városfejlesztési szempontból is a talaj-szennyezettség jelenti. Bár egzakt felmérés a területek pontos kiterjedéséről és a szennyezés mértékéröl még nem áll rendelkezésre, de több terület esetén feltárt és kimutatott szennyezésböl arra lehet következtetni, hogy más terület is érintett lehet e tekintetben.

A barnaövezeteket terhelö talajszennyezettség jelentősen hátráltatja a területek megújulását, funkcióváltását (Alvarez 2001; Nagy 2004; Priemus 2001). Különösen jellemző ez a nagy felületi kiterjedésủ szennyeződések esetén, illetve Duna parti elhelyezkedésü területeknél. A terület rehabilitációja, funkcióváltása a beruházás megtérülési rátáján túlmutató anyagi terheket ró a tulajdonosra, beruházóra. Nem csak a kármentesítés anyagi vonzata tántorítja el a beruházókat, hanem a nagyon időigényes engedélyezési- és kármentesítési folyamat is, amely a tényleges funkcióváltást megelőzi. A szennyezettség elözetes feltárása csak az elsö lépcsőfok, a további részletes vizsgálatok akár több évet is kitehetnek (ld. az Óbudai Gázgyár esetében). A beruházók nagy hányada ezért inkább a zöldmezős beruházások felé fordul. Vannak olyan területek, ahol az eredeti szennyezö már nem lelhető fel, ezért a kármentesítés vagy központi keretböl valósulhat meg, vagy az új tulajdonos vállalja a kármentesítés költségeit és procedúráját. Jellemzöen egyedi megoldások születnek a kárrendezésre. Közös finanszírozásra lehet jó példa a nagytétényi Metallochemia által okozott szennyezettség felszámolásának terve, amikor útépítés (M6) kapcsán nyílhat mód a probléma felszámolására, a terület rendezésére.

Nem kedvezö környezeti szempontból az az átmeneti állapot sem, amely a barnaövezeti területek egy részét ma jellemzi. Az átmeneti jellegủ hasznosítás a jellemzö, 
Kukely György - Barta Györgyi - Beluszky Pál - Győri Róbert: Barnamezős területek rehabilitációja Budapesten. - Tér és Társadalom, 20. 2006. 1. 57-71. p.

bérlemények hada lepi el a területet, a legkülönbözőbb funkciókkal. A területet ténylegesen használóknak a környezeti károk felszámolásában, a terület rendezésében nincs érdekeltségük, így a terület környezeti szempontból is mind inkább a gazdátlanság benyomását kelti.

Problémát jelent, hogy ma még nincs olyan jogi szabályozás, amely meghatározná a funkcióhoz, területhasználathoz rendelhető keretszámokat (határértékeket), és amely az egyes jövőbeni funkciók elhelyezésére alapot adhatna. Nem elhanyagolható ugyanis az a tény, hogy a szennyezett területeken milyen új funkció jelenik meg. A kármentesítés módja, nagyságrendje széles skálán mozoghat, de ehhez ismerni kell a terület további hasznosításának irányait.

\section{Városfejlesztés, városrendezés a barnaövezetben}

A szocializmusban a városfejlesztő-rendező politika nem tudta érdemlegesen befolyásolni az ipar területi elhelyezkedését a fövárosban. A szocialista rendszer nem volt érzékeny az ipari környezetszennyezés problémáira sem, ennek következtében a városfejlesztők nem tudtak érvényt szerezni a környezetvédelemmel kapcsolatos elveiknek. Ugyancsak nem figyeltek fel a városfejlesztők az iparnak (a városon belül is) több-telephelyes és ezért igen szállítás-igényes struktúrájára. A gazdaságpolitikusok kudarcot vallottak az iparkitelepítési programjukkal is (az 1960-as és 70-es években az erős nagyvállalatok eredményesen lobbiztak érdekeikért, például a kitelepítés megakadályozásáért).

A rendszerváltozás után alapvetỏ változások kezdődtek meg, melyekkel a városrendezési szabályozás ma is csak nehezen tud megbirkózni. A barnaövezet helyzetét leginkább a privatizáció súlyosbította. Az ingatlanok tulajdonosi szerkezete sokszor felaprózott, a telekrendezés mindmáig nem megoldott, ehhez nagy anyagi forrásokat igénylö magánútépítésre és közmürendezésre lenne szükség. Mivel az átalakítások kizárólag az összes tulajdonos engedélyével valósulhatnak meg, a területek előnytelen fizikai állapota rögzült. A területrendezés nem tudott lépést tartani a folyamatokkal, a közgazdasági és politikai szempontok a privatizáció fontosságát hangsúlyozták, gyakori volt az a vélemény, hogy az átalakuló iparterületek olcsó inkubátorterületek lehetnek a kialakuló piacgazdaságban (Locsmándi 2004). A fóvárosi és kerületi önkormányzatok közötti ellentét is sok problémát okozott. A Fővárosi Önkormányzat kijelölte azokat a területeket, amelyeket a város továbbra is ténylegesen ipartelepek számára kíván fenntartani. Ez kiváltotta a kerületek ellenállását, ugyanis egyikük sem akart saját területére ipart befogadni (not in my backyardpolitika). Így az a helyzet állt elö, hogy a város keretszabályzata tartalmaz ipari övezetekre vonatkozó határértékeket, ám iparterületek nincsenek ténylegesen kijelölve.

Habár a budapesti gazdaság továbbra is Magyarország gazdasági motorja, a politikai vezetés azonban - különböző okokból - nem vállalta fel a budapesti fejlesztéseket előtérbe helyező országépítő gazdaságpolitikát. Így, a fővárosban és térségében átgondolatlan, koordinálatlan fejlesztések zajlottak az elmúlt másfél évtizedben, amely sok veszteséggel, és elszalasztott lehetőséggel volt jellemezhető. Budapest, a 
Kukely György - Barta Györgyi - Beluszky Pál - Győri Róbert: Barnamezős területek rehabilitációja Budapesten. - Tér és Társadalom, 20. 2006. 1. 57-71. p.

budapesti agglomeráció valóságos, központi szerepe azonban egyre kevésbé kérdöjelezhetö meg, ez a térség egyre inkább felértékelödik a politikában is. Ez az értékváltás pozitív kihatással lesz a barnaövezet megújulására is.

- A jövőben a barnaövezet térszerkezeti változásaiban várhatóan folytatódni fog a „darabolós szétvásárlás” elsősorban azokban a térségekben, ahol e folyamatok már megindultak.

- Számítani lehet a nagyobb léptékü ingatlanfejlesztésekre (a Bosnyák tér, MOM, a budai Ganz, a Sportkórház máris jó példák erre). Ennek lehetőségét a köz- és a magánszféra együttműködése, valamint a városi közigazgatás szereplöinek remélhetö összefogása hozza majd magával.

- A korábbi gazdasági folyamatokat, föként a tercierizálódást, a későbbiekben bizonyos ipari tevékenységek továbbra is kiegészíthetik (ezt a folyamatot erősíti az életképes, nagy hozzáadott értéket teremtő iparok jelenléte - pl. gyógyszeripar, elektronika; a speciális és nagyméretú munkaerőpiac müködése; a klaszterizálódás, hálózatosodás elönyei; a transznacionális - globális gazdaságszerveződés érdekérvényesítése, s egyéb pozitív externális hatások). A budapesti metropolisz kialakulását segítő folyamatok terei egyaránt lehetnek a városon belüli barnamezők, illetve az agglomerációs gyürủ települései.

- Minden valószínúség szerint lesznek a barnaövezetben hosszabb idő alatt, nehezebben kezelhetö telephely-csoportok, ahol elöször a zavaros tulajdonviszonyokat kell rendezni (pl. Csepel Müvek, Ganz-MÁVAG területe stb.), másrészt átfogó környezeti kármentesítést kell végrehajtani. A korábbi iparterület, ill. a jelenlegi barnamezök egy része új hasznosításra vár.

- E térség lesz a kívánatos zöldterületi bövülés és más - még el nem döntött funkciók helye. E funkciók közül ki kell emelni a közlekedésfejlesztés jelentőségét, amely alapvetỏ és meghatározó eszköze az integrált térszerkezet kialakításának. Az urbanizációs folyamatok térszerkezeti és térhasználati változásai Budapesten egyelöre nem kerültek szinkronba a közlekedési technológia, elsősorban a motorizáció fejlődésével. Hálózati hiányosságok (a sugaras-gyủrüs hálózati rendszer haránt irányú elemeinek fejletlensége) és az ebből eredő zsúfoltság jellemzi a főváros megközelíthetőségét és belső forgalmát (a városrészek között jórészt csak a belvároson keresztül vezetnek utak; miközben a külsö városrészek között hiányzó közlekedési kapcsolatok hozzájárulnak e térségek leértékelödéséhez; a harántirányú kapcsolatok hiánya, valamint a vasúthálózat térséget felszabdaló hatása és nehéz átjárhatósága pedig lassítja, akadályozza a mai barnaövezet megújulását). A jövendöbeli fejlesztések a térszerkezet átalakításában nagy szerepet kapnak (2. ábra).

- A szuburbanizáció megköveteli a város és környékének közlekedési együttmüködését, eszközváltó zónák, intermodális csomópontok kialakítását. A vízi-légiközúti-vasúti kapcsolódások teljes rendszere, illetve ennek intermodális kapcsolatai Budapesten jórészt az átmeneti, illetve a barnaövezet területére esnek. Ennek érdekében magas színvonalú kötöttpályás kapcsolatokat kell kiépíteni az 
Kukely György - Barta Györgyi - Beluszky Pál - Györi Róbert: Barnamezős területek rehabilitációja Budapesten. - Tér és Társadalom, 20. 2006. 1. 57-71. p.

agglomerációs gyủrüt is elérve; gyorsvasúti kapcsolatokat a városközpont irányában; haránt irányú villamosvasúti kapcsolatokat a város más térségei felé; valamint a térséget minden irányban feltáró autóbuszkapcsolatokat kell bevezetni. A sürü vasúthálózatot integrálni kell a város és városkörnyéki közlekedési rendszerbe.

\section{2. ÁBRA}

Jelentös közlekedési vonalak fejlesztése a barnaövezetben

(Development of Significant Transportation Lines in the Brown Zone)

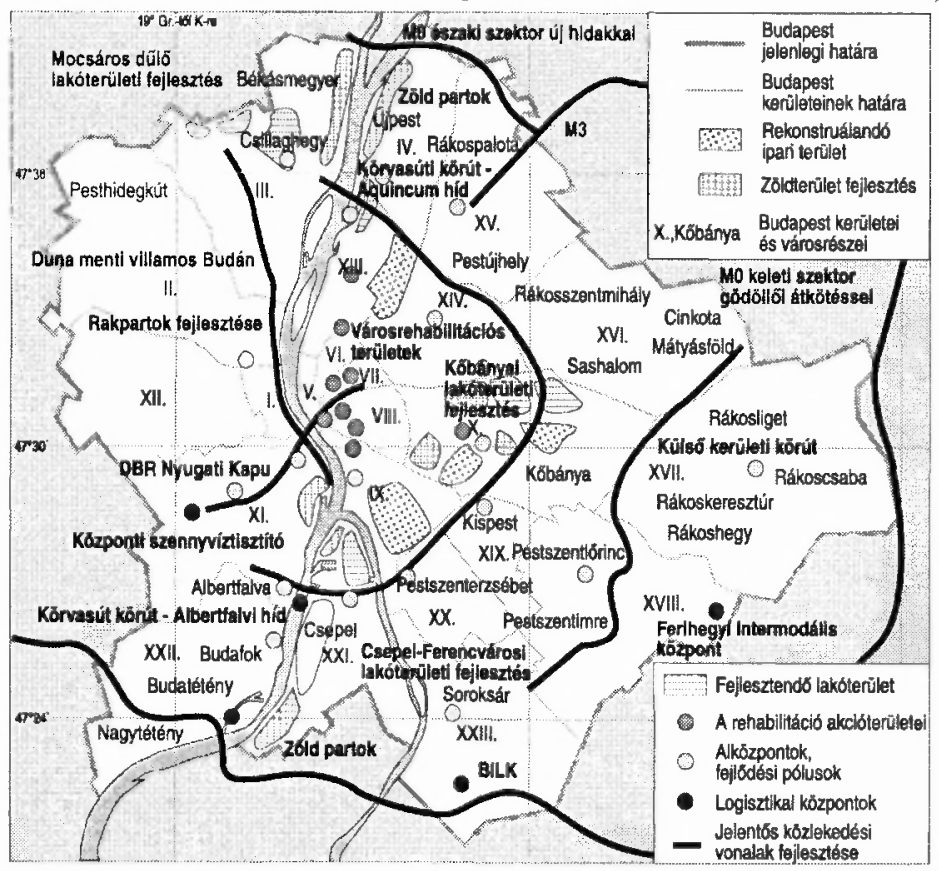

Forrás: Koszorú 2004.

A Budapest Városfejlesztési Koncepció (BVK) gerincét a 15 évre szóló stratégiai célok alkotják. A Fővárosi Önkormányzat a BVK elkészítésének megbízását 1997-ben adta ki, végülis 2003-ban fogadták el széleskörü politikai és szakmai egyetértéssel. 1998 és 2003 këzött több változat készült el, amelyek hangsúlybeli eltolódásokat is eredményeztek, s jǿl mutatják a komplex gondolkodásmódot követni szándékozó szakmai csopørt és a pøitikai és pénzügyi szorításban mủködő városvezetés közötti kømprømisszumkeresés különböző fázisait (Tosics 2004). A BVK első, 1998-as váltezata a barnaövezet problémáját a belvárosi rehabilitációt követő, ám a lakótelepek felújítását megelőző prioritásként határozza meg.

A javasolt jövőkép három programelemen nyugszik:

- funkcióváltás, hiányzó belső területi és elővárøsi funkciók fogadása,

- szerkezetátalakítás és struktúraadás, a térségi és övezeti prioritások kijelölésével és fejlesztési szabályezásával,

- hálézatépítés, a terület feltárása, a belső vár si térségek tehermentesítése. 
Kukely György - Barta Györgyi - Beluszky Pál - Győri Róbert: Barnamezős területek rehabilitációja Budapesten. - Tér és Társadalom, 20. 2006. 1. 57-71. p.

A megújuláshoz szükséges intézmény- és eszközrendszerre is javaslatot tesz a BVK, eszerint szuikséges, hogy a Fővárosi Önkormányzat szabályozási ereje növekedjen, területileg differenciált iparủzési adót vezessenek be, az önkormányzatok a koncepcióhoz igazított aktív telekpolitikát folytassanak, valamint hogy a fejlesztések koordinálására nonprofit fejlesztö vállalatokat hozzanak létre ( $B V K$ 1998). A BVK első változata alkalmas lett volna arra, hogy erre alapozva politikai döntés szülessen, így gyorsan és jobb eséllyel kezdödhetett volna el a megvalósítás. A politika azonban nem ismerte fel a gyors döntés elönyeit, a szakértők pedig egyes problémák mélyebb elemzését látták szükségesnek, így egy 2003 tavaszáig húzódó egyeztetési folyamat indult meg. Ezek alapján a föváros elvetette a barnaövezeti rehabilitáció egyedüli vezérprojektként való meghatározását, nem tartotta megvalósíthatónak az aktív telekpolitikát (a telekfelvásárlásokra nincs elég pénzuigyi forrás), a nonprofit fejlesztő vállalatok létrehozását és az aktív gazdaságpolitikát. Az átmeneti zóna megújítása csak egy lett a stratégiai célok között, és megfogalmazták az alapvetö dilemmát is: a területi tartalékok feltárása mindenképpen elönyökkel járna Budapest számára, ám a megvalósítás meghaladja a fỏváros hatáskörét és anyagi lehetőségeit.

A 2003-ban elfogadott BVK középpontjába a stratégiai jelentőségü fejlesztésnek tekintett Körvasúti körút megvalósítása került, mely a térszerkezet arányos fejlödését, a belső és külső városrészek összekapcsolását, a barnaövezet gazdasági megújulását fogja remélhetően biztosítani. A Körvasúti körút keleti szektora a területfejlesztés megkülönböztetett célterülete, a körút által feltárt területen magas presztízsü kertváros létrehozását irányozták eló.

A koncepcióban megjelent reurbanizációs jellegü mintaprojektekben (ÉszakBuda, Csepel és Dél-Budapest) a korábban ipari-szolgáltató területhasználatot új, városi funkciók váltanák fel. Ezeket beillesztették Budapest Középtávú Városfejlesztési (, Podmaniczky”) Programjába. A Podmaniczky Program a Fövárosi Önkormányzat 2013-ig szóló programja, amely 9 év alatt megvalósuló 130 fejlesztési projektet tartalmaz - a Fövárosi Önkormányzat, a közszféra és a magángazdaság közös beruházásaival. A gazdasági versenyképességet erösítő programokhoz az Európai Unió támogatást nyújt a Strukturális Alapokból, és - elsösorban a közlekedés fejlesztéséhez - a Kohéziós Alapból. Ezzel megnyílik a lehetőség arra, hogy Budapest és régiója kedvezőbb pozíciót foglaljon el a nagyvárosi régiók európai hálózatában.

Az ún. Budapesti Magprogram tartalmazza a Podmaniczky Program szükített változatát, amelynek megvalósítása - a már jelenleg is reális pénzügyi források keretei között - prioritást élvez. Középpontjában a közösségi közlekedés és a tudásvárosi funkciók megerösítése, a környezetbarát gondolkodás és a fenntartható városfejlesztés áll. A barnaövezet rehabilitációja a Podmaniczky Program több projektjéhez kapcsolódik.

- A 7 kiemelt fejlesztési térség egyike a belsö-átmeneti zóna (Keleti kapu), amely a Középső-Józsefváros leromlott lakóterületeit, a Kőbányai út belső szakaszának barnaövezetét, a már kiépített, de minöségében elmarasztalható zöldfelületeket (a Népligetet és az Orczy-kertet) foglalja magában. A program- 
Kukely György - Barta Györgyi - Beluszky Pál - Györi Róbert: Barnamezős területek rehabilitációja Budapesten. - Tér és Társadalom, 20. 2006. 1. 57-71. p.

térség komplex fejlesztésében megjelennek a lakóterületi, kulturális-rekreációs célok, valamint a kereskedelmi-ipari szempontok.

- A tematikus programok közül kiemelhetö a lakó- és közterületi rehabilitáció felgyorsítása a barnaövezetben, ahol cél a társadalmi szegregáció enyhítése, valamint a szociális városrehabilitációs program elindítása a kooperációra kész kerületekkel.

- A zöldfelület fejlesztés egyik kiemelt térsége a barnaövezet. A városrehabilitáció része a nagyméretủ parkok kialakítása (pl. a Csepel-sziget csúcsán), a térség folyó és patak partjainak kultúrált kiépítése.

- Az átmeneti zóna problémája és egyben lehetósége is a volt ipari, a kiürült vasúti (MÁV) és honvédelmi területek újra hasznosítása más célokra. A Fövárosi Önkormányzat koordinálásával kell megindítani a barnaövezeti rehabilitációban érdekelt szereplök közötti kommunikációt.

A Budapesti Magprogramban is megjelennek a barnaövezeti rehabilitáció projektjei. A legelső feladat a barnamezös térségek kármentesítése - a beruházók számára potenciálisan legvonzóbb térségekben (az Óbudai Gázgyár területén, a Rákosrendezö, a Ganz, a Józsefvárosi és Ferencvárosi pályaudvar térségeiben). Egyes esetekben a terület hasznosításának, funkcióbővítésének elökészítő feladatait is el kell végezni, ki kell dolgozni a revitalizációs projekteket. Azokon a területeken, ahol a fővárosi tulajdon korlátozott, a PPP konstrukciók megvalósítása indokolt. Az ilyen fejlesztésekben a Fővárosi Önkormányzat aktív koordináló szerepet tölt be, kidolgozza a fejlesztés koncepcioját és szabályozási hátterét.

\section{Befejezés}

A magyarországi barnamezős területek 40\%-a Budapesten található (VÁTI 2003), nem véletlen, hogy a barnamezős rehabilitáció kérdése markánsan jelentkezik a fővárosban. A barna zónák igen nagy értéket jelentenek a település számára, amennyiben megtörténik rehabilitációjuk, újrahasznosításuk. Az elmúlt tizenöt évben a budapesti barnaövezet egy része jelentős átalakuláson, funkcióváltáson ment át, elősegítve kisebb-nagyobb városrészek modernizálódását, korszerủ átalakulását. Ugyanakkor hatalmas területek alulhasznositottak, elhagyottak, vagy csak ideiglenes használat jellemző rájuk, s komoly környezeti gondokkal küzdenek. A sikeres barnamezỏs megújítási stratégiáknak és politikáknak a környezeti perspektívákat is magukba foglaló városfejlesztési tervezésbe kell illeszkedniük, annak érdekében, hogy e térségek számára megtalálják az újrahasznosítás legkedvezőbb módjait. A barnamezős rehabilitáció jelentős teret kapott a Budapesti Városfejlesztési Koncepcióban és Programban is. A rehabilitáció hozadékaként a városszerkezeti problémák is csökkenthetők, a barnamezős területeken fenntartható és gazdaságos területfelhasználás jön létre, s megtörténik az épületvagyon és a meglévő infrastruktúra újrahasznosítása. A környezeti kármentesítés révén létrejövő tisztább és jobb fizikai környezet egyaránt hozzájárul a növekvő ingatlanértékhez, s a befektetök vonzásához. 
Kukely György - Barta Györgyi - Beluszky Pál - Győri Róbert: Barnamezős területek rehabilitációja Budapesten. - Tér és Társadalom, 20. 2006. 1. 57-71. p.

70 Kukely Gy.-Barta Gy.-Beluszky P.-Györi R. TÉT XX. évf. 2006

\section{Irodalom}

Alker, S.-Joy, V.-Roberts, P.-Smith, N. (2000) The Definition of Brownfield. - Journal of Environmental Planning and Management. 1, 49-69, o.

Alvarez K. (2001) A barnamezök és rozsdaövezetek gazdasági újjáélesztési programja az Egyesült Államokban. - Éri V. (szerk.) Terjeszkedés vagy ésszerü városfejlödés? Környezettudományi Központ, Budapest. 75-79. o.

Barta Gy. (témavezetö) (2002) Gazdasági átalakulás Budapest barnaövezetében. MTA RKK KÉTI, Budapest.

Barta Gy. (témavezetö) (2004a) Rehabilitációs megoldások az európai nagyvárosok barnaövezetében. MTA RKK KÉTI, Budapest.

Barta Gy. (szerk.) (2004b) A budapesti barnaövezet megújulási esélyei. MTA Társadalomkutató Központ, Mühelytanulmányok, Budapest.

Beluszky P.-Györi R. (2004) A budapesti barnaövezet határai. - Barta Gy. (szerk.) A budapesti barnaövezet megújulási esélyei. Magyarország az ezredfordulón, MTA Társadalomkutató Központ, Budapest. 71-76. o.

BVK (1998) Budapest Városfejlesztési Koncepciója. Egyeztetési anyag. Budapest.

BVK (2002) Budapest Városfejlesztési Koncepciója. Budapest.

Ferber, U.-Grimski, D (2002) Brownfields and Redevelopment of Urban Areas. CLARINET Group. Austrian Federal Environment Agency.

Jackson, J.-Garb, Y. (2002) Facilitating brownfield redevelopment in Central Europe: overview and proposals. Institute for Transport and Development Policy, Prague.

Kiss É. (1999) Térszerkezeti és funkcionális változások Budapest ipari területein 1989 után. - Tér és Társadalom. 4. 119-133. o.

Koszorú L. (2004) Térszerkezet és barnaövezet. - Barta Gy. (szerk.) A budapesti barnaövezet megújulási esélyei. Magyarország az ezredfordulón, MTA Társadalomkutató Központ, Budapest. 303-327. o.

Locsmándi G. (2004) A városrendezési szabályozás korlátozott szerepe az átalakuló budapesti iparterületeken. - Barta Gy. (szerk.) A budapesti barnaövezet megijulási esélyei. Magyarország az ezredfordulón, MTA Társadalomkutató Központ, Budapest. 257-274. o.

Nagy K. (2004) Kömyezetállapot jellemzöi a budapesti bamaövezetben.- Barta Gy. (szerk.) A budapesti barnaövezet megújulási esélyei. Magyarország az ezredfordulón, MTA Társadajomkutató Központ, Budapest. 89-108. o.

Podmaniczky Program (2005) Budapest Középtávú Városfejlesztési Programja 2005-2013. Budapest Föváros Önkormányzata, Budapest.

Priemus H. (2001) Barnamezös területek felújítása és várospolitika Nyugat-Európában - Hollandia példája. - Éri V. (szerk.) Terjeszkedés vagy ésszerü városfejlödés?" Környezettudományi Központ, Budapest. 80-84. o.

Tosics I. (2004) Elképzelés az átmeneti zóna és a barnaövezet jövöjére a Budapest Városfejlesztési Koncepciójában és a kidolgozás alatt álló Középtávú Városfejlesztési Programjában.- Barta Gy. (szerk.) A budapesti barnaövezet megújulási esélyei. Magyarország az ezredfordulón, MTA Társadalomkutató Központ, Budapest. 327-343. o.

VÁTI (2003) Az EU Strukturális Alapok keretében barnamezös rehabilitációra kiírandó pályázatok szakmai megalapozása. VÁTI Kht. Településtervezési és Tájtervezési Iroda, Budapest.

\section{REHABILITATION OF BROWNFIELDS IN BUDAPEST}

\section{GYÖRGY KUKELY - GYÖRGYI BARTA - PÁL BELUSZKY - RÓBERT GYÖRI}

The brownfield belt of the Hungarian capital comprises an area of 68 square kilometres where once large industrial production sites were located. Some patches of this zone already show signs of rehabilitation, but generally speaking, any effort of the Budapest brownfield rehabilitation faces formidable challenges. The level of environmental pollution, including soil pollution, is high, housing estates are in bad condition, and the Hungarian state railway system still owns many unused, obsolete, empty and ruined buildings and other real estate 
within this brownfield area. Spontaneous functional changes are good signs, but they are not part of a planned process and represent often only interim solutions. In addition, they utilise only small parts of the brownfield area. However, this area could be promising for metropolitan development and become an important economic factor in the future. City planners and researchers agree that the time has come to find practicable solutions to change the colour of the brownfields. 